\title{
EFFECT OF DIETARY ENERGY LEVELS WITH OR WITHOUT SELENIUM AND CHOLINE SUPPLEMENTATION ON PERFORMANCE OF BROILER CHICKENS
}

\author{
R.M.S. Emam \\ Poultry Production Department, Faculty of Agriculture, Fayoum University, Egypt.
}

(Received 6/9/2018, accepted 17/10/2018)

\section{SUMMARY}

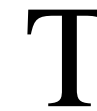

his research was conducted to study the impact of using two levels of ME (recommended (R) and $\mathrm{R}-150 \mathrm{Kcal} / \mathrm{Kg}$ diet) and each with four type of addition (without Se or choline supplementation, 0.1 $\mathrm{mg} \mathrm{Se} / \mathrm{Kg}$ diet in the form of organic Se as Sel-Plex (Se yeast), $0.10 \%$ of choline and $0.05 \mathrm{mg} \mathrm{Se} / \mathrm{Kg}$ diet $+0.05 \%$ choline in $2 \times 4$ factorial arrangement (giving eight dietary treatments) on growth performance of Cobb broiler chickens. Accordingly, a total number of 192 one-day old unsexed Cobb broiler chickens were firstly fed a control diet for five days. At six day of age, chicks were randomly allotted to the dietary treatments, birds were divided into eight treatments ( 24 birds each) and each treatment contained three replicates (eight birds each). Results obtained could be summarized in the following:

Performance: Chicks fed diet containing recommended level of ME (R)-150 Kcal/Kg diet had significantly higher values of LBW at 41 days and LBWG, FI, GR, PI during the period from 6 to 41 days, while, chicks fed diet containing $\mathrm{R}$ had significantly lower values during the same previous periods. Chicks fed R-150 Kcal/Kg had the best FC, CPC and CCR during the period from 25 to 41 days, and those fed R-150 Kcal/Kg had the best CCR during the period from 6 to 41 days. Type of addition and interaction due to level of ME effect X type of addition (experimental treatments) had insignificant effect on LBW, LBWG, FC, CPC, CCR, GR and PI during the periods from 25 to 41 and 6 to 41 days (finisher and over all experimental period). Chicks fed diet containing R with $0.05 \mathrm{mg} \mathrm{Se} / \mathrm{Kg}$ diet and $0.05 \%$ choline had higher value of FI during the period from 6 to 41 days.

Slaughter parameters\% and blood constituents: neither level of ME, type of addition nor interaction due to level of ME effect $\mathrm{X}$ type of addition had any significant effect on slaughter parameters\% and blood constituents except, type of addition with dressing\% and bursa, which was significantly affected. Chicks fed diet containing $0.1 \mathrm{mg} \mathrm{Se} / \mathrm{Kg}$ diet as Sel-Plex had higher value of dressing percentage. Also, interaction due to level of ME effect $\mathrm{X}$ type of addition, which was significantly affected of total leucocytes. Chicks fed diet containing R-150 Kcal/Kg diet with $0.1 \%$ choline had higher value of total leucocytes at the end of the experiment. GSH-PX activity were significantly $(\mathrm{P} \leq 0.01)$ affected by level of ME and type of addition, chicks fed $0.1 \mathrm{mg} \mathrm{Se} / \mathrm{Kg}$ diet as Sel-Plex had higher value of GSH-PX at 41 days.

Chemical composition of broiler meat: Level of ME, type of addition and interaction due to level of ME effect X type of addition had insignificant effect on chemical composition of broiler meat, except, moisture \%, which was significantly affected.

Economic efficiency (EEf): EEf values during the period from 6 to 41 days of age improved in chicks fed all experimental diets, except, chicks fed diet containing recommended level of ME with $0.05 \mathrm{mg} \mathrm{Se} / \mathrm{Kg}$ diet as Sel-Plex plus $0.05 \%$ choline (the lowest corresponding values, being 0.126 and $95.74 \%$, respectively), as compared with those fed the control diet. Chicks fed diet 7 (R-150 Kcal/Kg diet plus $0.1 \%$ choline) had the best Economic and relative efficiency values being 0.251 and $191.34 \%$, respectively.

It would be concluded that: It can be concluded that, dietary ME can be reduced from the recommended level up to $150 \mathrm{Kcal} / \mathrm{Kg}$ diet and supplement these diets with $0.1 \mathrm{mg} \mathrm{Se} / \mathrm{Kg}$ diet as Sel-Plex or $/ \mathrm{and} 0.1 \%$ choline without affecting Cobb broiler performance.

Keywords: energy, selenium, choline, broiler, performance. 


\section{Emam}

\section{INTRODUCTION}

In Egypt, poultry production has become one of the biggest agriculture industries, and its development is a major goal of broiler producers. Furthermore, feeding cost represents the major parts of total cost in poultry production, especially dietary energy sources and optimal energy level is important for decreasing feed cost per unit of poultry product. Efforts to reduce dietary energy and improving utilization of common feeds by using some additives have been the subject of much research. Adequate energy intake is very imperative for broiler since any excess of energy consumption is deposited mainly as fat in the body which indicating the wastage of dietary energy. Broiler obesity is normally coupled with lower production and feed efficiency (Ghaffari et al., 2007). Moreover, obesity in poultry increases the incidence of reproductive failure, death due to heart diseases and impaired thermoregulation (Garlich, 1979). So, we need to provide adequate energy intake to get best performance and economic. The metabolizable energy (ME) content of rations has been decreased over time, a fact that well associate with improved efficiency. Feed additives are essential materials that can improve the efficiency of feed utilization, performance of poultry and immune response to diseases. Vitamins and minerals addition of commercial compound feed as a single or in combination are mostly oriented towards recommendations for addition of choline and selenium.

Selenium (Se) is a dietary essential trace element for broiler nutrition. The broiler chicken's requirement for Se has been given as $0.15 \mathrm{ppm}$ (NRC, 1994). Se requirement is quite low, while, this level is not related to commercial conditions and physiological functions of poultry production and it seems likely Se requirement for optimal broiler health is much higher ( $\mathrm{Li}$ and Sunde, 2016). The maximum allowed level of Se in the United States is $0.3 \mathrm{ppm}$, while, the maximum allowed Se inclusion level is $0.5 \mathrm{ppm}$ (European Commission, 2014).

Generally, the chemical dietary form of Se is a major determinant of its bioavailability. Selenium has been added to broiler diets namely inorganic sources (sodium selenite, $\mathrm{Na}_{2} \mathrm{SeO}_{3}$ ) or (selenate, $\mathrm{Na}_{2} \mathrm{SeO}_{4}$ ), or as organic Se derived from yeast (Saccharomyces cerevisiae), mainly selenomethionine and analogues (Burk and Hill, 2015). Organic Se is a highly available form of Se for chickens than inorganic Se in sodium selenite (Mahmoud and Edens, 2003). Organic Se compounds generally have higher efficacy and biological activities, less toxicity compared with inorganic Se (Briens et al., 2013), thus varieties of Se-enriched biological products have been commercialized.

Microorganism fermentation with Se technique provides a feasible and economic approach for production of organic Se compounds (Zhang et al., 2008). So, organic sources of Se such as Sel-Plex, a Se yeast have been explored as an alternative to inorganic form in animal diets (Payne et al., 2005 and Payne and Southern, 2005). A number of studies reported that Se supplementation at 0.2-0.3 ppm in the organic form as Sel-Plex provides optimum Se status for broiler growth and development. Organic Se is proven to be an effective diet supplement to meet broiler requirement from this element in various commercial conditions and physiological functions Papazyan et al. (2006). In addition, the use of organic Se results in less Se being transferred to the environment through feces and more Se is deposited into body tissues and eggs (Payne et al., 2005, Payne and Southern 2005 and Utterback et al., 2005). Advantages of organic Se in the form of Seyeast for broilers include improvement of growth rate, FCR, lower mortality and drip loss during meat storage Papazyan et al. (2006). Se from Se yeast $(0.2 \mathrm{mg} / \mathrm{kg})$ was used more efficiently for performance in high yielding or fast growing broiler chickens (Upton et al., 2008).

There are many demonstrations of potential positive impacts of Se supplementation to increase broiler resistance against major pathogens and/or alleviate consequences of environmental stresses (Dalgaarda et al., 2018). Selenium is a cofactor of large numbers of Se dependent antioxidant enzymes such as glutathione peroxidase (GSH-Px) activities, which protects the cell and membranes from severe oxidation caused by free radicals (Rotruck et al., 1973 and Singh et al., 2006). Furthermore, Klasing (1998) reported that chronically severe deficiencies of micronutrients are more debilitating to the development of the immune system than deficiencies of dietary energy and protein.

Choline is an absolutely charged quaternary amine, water soluble nutrient that has been grouped inside the B-complex (no resemblance to the B vitamins) vitamins (Zeisel et al., 1991). While, other author has theorized that adequate nutrition requires dietary choline, but this nutrient is not a vitamin, its metabolism are more akin to the amino acids than any other class of nutrients (Garrow, 2007). Wu and Davis (2005) demonstrated that choline chloride (metabolized into choline in the body) is an effective source of choline in the poultry diets (100\% bio-available). According to McDowell (2000), poultry requirements for choline are 
in the range of 300-2000 mg/kg diet. Choline cannot be stored in the body so choline in excess of essential needs is oxidized to betaine (Wang et al., 2004). Betaine has a more pronounced effect when dietary energy and FI are limiting (Dunshea et al., 2009). According to Garrow (2007), the oxidation of choline is an energy yielding process.

Choline is an essential nutrient for the poultry and for prevention of perosis in chicken. One of choline functions is to give methyl groups that can also be furnished by methionine, betaine and folate, that act as Sadenosine methionine metabolism, methylation of DNA, RNA, protein and histone as illustrated by Pillai et al. (2006) and Dunlevy et al. (2006). Therefore, the level of choline in the poultry diet can affect the methionine requirement (Harms et al., 1990), but choline cannot reduce the need for methionine if the diet does not contain enough choline (McDevitt et al., 2000). Choline is important as a constituent of phospholipids in cell membranes, methyl metabolism and hepatic lipid metabolism to prevent fatty liver, cholinergic neurotransmission and precursor acetylcholine (Workel et al., 1999). Finkelstein (2000) reported that choline interacts with methionine and folate to achieve this one carbon methylation and decrease the amount of homocysteine which be toxic in high levels. In the case of choline deficiency, Niculescu et al. (2006) reported that modifying the intake of choline nutrients could alter lipid metabolism and methylation.

Information are lacking on the use of choline and/or Se at low level of ME. The present study therefore evaluated effects of Se (Sel-Plex (SP, Alltech Inc., Nicholasville, KY), a Se yeast) and/ or choline as feed additives in broiler diets at low level of ME on performance and some physiological response of broiler chickens.

\section{MATERIALS AND METHODS}

This study was carried out at the Poult. Res. Station, Ministry of Agric. and Land Recl., Regional Councils for Agric. Res. and Extension, Fayoum, Egypt, during the period from Jan. to Feb., 2016. Chemical analyses were performed in the laboratories of Poult. Prod. Dep., Faculty of Agric., Fayoum University according to the methods outlined by A.O.A.C (1990).

This research was conducted to study the impact of using two levels of ME (recommended (R) and R-150 $\mathrm{Kcal} / \mathrm{Kg}$ diet) and each with four type of addition (without Se or choline supplementation, $0.1 \mathrm{mg} \mathrm{Se} / \mathrm{Kg}$ diet in the form of organic Se as Sel-Plex (Se yeast), $0.10 \%$ of choline (dry choline chloride $(0.167 \%)$ product (60\% choline) were added to the diets) and $0.05 \mathrm{mg} \mathrm{Se} / \mathrm{Kg}$ diet $+0.05 \%$ choline in $2 \times 4$ factorial arrangement (giving eight dietary treatments) on growth, feed utilization and Economic efficiency of Cobb broiler chicks. Se yeast as Sel-Plex (Alltech Inc.) contains $1000 \mathrm{mg} \mathrm{Se} / \mathrm{Kg}$ Sel-Plex and created by the fermentation of yeast (Saccharomyces cerevisiae) in a high Se medium.

Accordingly, a total number of 192 one-day old unsexed Cobb broiler chickens were originally fed a control diet for five days. Chicks were weighed (individually) to the nearest gram at six days of age (start of experiment), wing banded and randomly allotted to the dietary treatments, birds were divided into eight treatments (24 birds each) and each treatment contained three replicates (eight birds each). Chicks were raised in electrically heated batteries with raised wire mesh floors and had a free access of mach feed and fresh water from nipple drinkers $\{2$ nipples/cage $\}$ throughout the experiment. The experimental treatments were as follows:

1. Chicks were fed the control diet $\left(\mathrm{D}_{1}\right)$. 2. $\mathrm{D}_{1}+0.1 \mathrm{mg} \mathrm{Se} / \mathrm{Kg} \operatorname{diet}\left(\mathrm{D}_{2}\right)$.

3. $\mathrm{D}_{1}+0.1 \%$ choline $\left(\mathrm{D}_{3}\right)$. $\quad$ 4. $\mathrm{D}_{1}+0.05 \mathrm{mg} \mathrm{Se} / \mathrm{Kg}$ diet $+0.05 \%$ choline $\left(\mathrm{D}_{4}\right)$.

5. $\mathrm{D}_{1}-150 \mathrm{Kcal} / \mathrm{Kg} \operatorname{diet}\left(\mathrm{D}_{5}\right)$. $\quad$ 6. $\mathrm{D}_{1}-150 \mathrm{Kcal} / \mathrm{Kg} \operatorname{diet}+0.1 \mathrm{mg} \mathrm{Se} / \mathrm{Kg} \operatorname{diet}\left(\mathrm{D}_{6}\right)$.

7. $\mathrm{D}_{1}-150 \mathrm{Kcal} / \mathrm{Kg}$ diet+ $0.1 \%$ choline $\left(\mathrm{D}_{7}\right)$.

8. $\mathrm{D}_{1}-150 \mathrm{Kcal} / \mathrm{Kg}$ diet+ $0.05 \mathrm{mg} \mathrm{Se} / \mathrm{Kg}$ diet $+0.05 \%$ choline $\left(\mathrm{D}_{8}\right)$.

The composition and calculated analysis of the experimental diets (without $\mathrm{Se}$ or choline supplementation) are presented in Table (1). The experimental diets were supplemented with vitamins and minerals mixture, to cover the recommended requirements according to the strain catalog recommendations and were formulated to be iso-nitrogenous.

Batteries were placed into a room provided with a continuous ( 23 hour/day up to 41 days of age) light and fans for ventilation. The experimental birds were reared under similar (open system) environmental conditions and were fed with broiler starter diet from 6 to 12 days of age, broiler grower diet from 13 to 24 
days and broiler finisher diet from 25 to 41 day (the end of the experiment). Room temperature on day 0 was $35^{\circ} \mathrm{C}$ and $33^{\circ} \mathrm{C}$ at the end of first week and decreased approximately $2^{\circ} \mathrm{C}$ per week until $23^{\circ} \mathrm{C}$ was reached, according to standard poultry rearing practices. The vaccination program, adopted by recommended requirements according to standard commercial guidelines. Birds were weighed (individually) to the nearest gram at 6,12, 24 and 41 days intervals during the experimental period.

Table (1): Composition and calculated analyses of the experimental diets.

\begin{tabular}{|c|c|c|c|c|c|c|}
\hline \multirow[b]{2}{*}{ Item, \% } & \multicolumn{2}{|c|}{ Starter (6-12 days) } & \multicolumn{2}{|c|}{ Grower (13-24 days) } & \multicolumn{2}{|c|}{ Finisher (25-41 days) } \\
\hline & Control & $\begin{array}{c}\text { Control } \\
-150 \text { Kcal. }^{1}\end{array}$ & Control & $\begin{array}{c}\text { Control } \\
-150 \text { Kcal. }\end{array}$ & Control & $\begin{array}{c}\text { Control } \\
-150 \text { Kcal. }\end{array}$ \\
\hline Yellow corn, ground & 55.90 & 58.90 & 60.40 & 64.54 & 62.90 & 66.42 \\
\hline Soybean meal (44\%CP) & 36.85 & 36.58 & 31.66 & 30.50 & 28.61 & 27.89 \\
\hline Calcium carbonate & 1.00 & 1.00 & 1.00 & 1.00 & 0.90 & 0.90 \\
\hline Sodium chloride & 0.40 & 0.40 & 0.40 & 0.40 & 0.40 & 0.40 \\
\hline Vit. and trace Min. premix ${ }^{2}$ & 0.30 & 0.30 & 0.30 & 0.30 & 0.30 & 0.30 \\
\hline Dicalcium phosphate & 2.20 & 2.20 & 2.10 & 2.02 & 2.00 & 2.00 \\
\hline Vegetable oil $^{3}$ & 3.20 & 0.50 & 4.00 & 1.08 & 4.70 & 1.90 \\
\hline DL-Methionine & 0.15 & 0.12 & 0.13 & 0.13 & 0.13 & 0.13 \\
\hline L-Lysine Hcl & 0.00 & 0.00 & 0.01 & 0.03 & 0.06 & 0.06 \\
\hline Total & 100.0 & 100.0 & 100.0 & 100.0 & 100.0 & 100.0 \\
\hline \multicolumn{7}{|l|}{ Calculated analysis $^{4}$ : } \\
\hline Crude protein & 21.06 & 21.18 & 19.16 & 19.02 & 18.07 & 18.06 \\
\hline Ether extract & 5.62 & 3.04 & 6.55 & 3.78 & 7.32 & 4.65 \\
\hline Crude fiber & 3.81 & 3.86 & 3.55 & 3.56 & 3.39 & 3.42 \\
\hline Calcium & 0.98 & 0.98 & 0.95 & 0.93 & 0.88 & 0.88 \\
\hline Available phosphorus & 0.54 & 0.54 & 0.51 & 0.50 & 0.49 & 0.49 \\
\hline Methionine & 0.48 & 0.45 & 0.43 & 0.43 & 0.42 & 0.42 \\
\hline Methionine+Cystine & 0.82 & 0.80 & 0.75 & 0.75 & 0.72 & 0.72 \\
\hline Lysine & 1.14 & 1.14 & 1.02 & 1.01 & 0.98 & 0.97 \\
\hline Sodium & 0.17 & 0.17 & 0.17 & 0.17 & 0.17 & 0.17 \\
\hline Chloride & 0.28 & 0.28 & 0.28 & 0.28 & 0.28 & 0.28 \\
\hline Selenium, mg Se /Kg diet & 0.154 & 0.154 & 0.150 & 0.150 & 0.148 & 0.148 \\
\hline $\mathrm{ME}, \mathrm{Kcal} . / \mathrm{Kg}$ & 2991 & 2842 & 3098 & 2949 & 3179 & 3029 \\
\hline $\mathrm{C} / \mathrm{P}$ ratio & 142.0 & 134.2 & 161.7 & 155.1 & 175.9 & 167.7 \\
\hline Cost $(£ . E . / \text { ton })^{6}$ & 5918 & 5674 & 5759 & 5480 & 5704 & 5451 \\
\hline Relative $\operatorname{cost}^{7}$ & 100.0 & 95.88 & 100.0 & 95.16 & 100.0 & 95.56 \\
\hline $\begin{array}{l}{ }^{1} \mathrm{ME}, \mathrm{Kcal.} / \mathrm{Kg} \text { diet. } \\
\text { contains: Vit. A } 10000000 \mathrm{IU} \text {; } \\
\text { Vit. } \text { B }_{6} 1500 \mathrm{mg} ; \mathrm{Vit} . \mathrm{B}_{12} 10 \mathrm{mg} \\
\mathrm{g} ; \mathrm{Fe} 30 \mathrm{~g} ; \mathrm{Co} 0.1 \mathrm{~g} ; \text { Se } 0.1 \mathrm{~g} ; \\
{ }^{3} \text { Mixture from } 75 \% \text { soybean oi }\end{array}$ & $\begin{array}{l}3 \mathrm{~g} ; \mathrm{Mn} \\
\text { nd } 25 \% \text { sur }\end{array}$ & the Vit. and $t$ & e Min. pre & manufactu & by Vetgree & $\begin{array}{l}\text { Company anc } \\
\text { it. } B_{2} 500 \mathrm{mg} \\
\mathrm{Zn} 50 \mathrm{~g} ; \mathrm{Cu} \\
\text { carbonate. }\end{array}$ \\
\hline
\end{tabular}

At the same time, feed consumption was recorded and feed conversion (FC, $\mathrm{g}$ feed/g gain) and live body weight gain (LBWG) were calculated. Crude protein conversion (CPC), caloric conversion ratio (CCR), growth rate $(\mathrm{GR})$ and performance index (PI) was calculated according to the equation described by North (1981) as follows: $\mathrm{PI}=(\mathrm{LBW}, \mathrm{Kg} / \mathrm{FC}) \mathrm{x} 100$.

Accumulative mortality rate was obtained by adding the number of dead birds during the experiment divided by the total number of chicks at the starting of the experimental period (mortality \% was within normal range and not related to treatments studied). At 41 days of age (end of the finishing period), slaughter tests were performed using three chicks around the average LBW of each treatment. The birds were on feed withdrawal (approximately 16 hour) overnight, then weighed (individually) to the nearest gram, and slaughtered by severing the jugular vein. After five minutes bleeding time, each bird was dipped in a water bath $\left(79^{\circ}\right)$ for $30 \mathrm{~s}$, and feathers were removed mechanically. After the removal of head, carcasses were manually eviscerated, by the same person to ensure uniformity of cuts, to determine some carcass traits, 
dressing $\%$ \{eviscerated carcass without legs, head and neck\} and total giblets $\%$ \{liver, heart, gizzard empty and spleen $\}$. The eviscerated weight included the front part with wing and rear part. The abdominal fat was removed by hand from the parts around the gizzard and viscera, and was weighed to the nearest gram. The bone of front and rear were separated and weighed to calculate meat\%. The meat (without the skin) from each part was weighed, and blended using a kitchen blender.

At the time of slaughter test, individual blood samples were taken from three birds of each treatment to determine hematological and biochemical characteristics of blood. Glutathione peroxidase (GSH-Px) activity was determined in plasma via enzymatic methods; adjusted for poultry blood, using available commercial kits SCLAVO INC.; 5 Mansard Count.; Wayne NJ 07470, USA.

Chemical analyses of representative samples of the carcass meat without the skin were carried out to determine $\mathrm{DM}, \mathrm{CP}=(\mathrm{N} \times 6.25)$, $\mathrm{EE}$ and ash contents according to the methods of A.O.A.C. (1990). Nitrogen free extract (NFE) was calculated by difference. To obtain bone ash values, the right tibia bone was collected according to the method of Martinez et al. (2006). Tibias were pooled by replicate groups and autoclaved and adhering tissue was removed. Then bones were dried for 24 hour at $100^{\circ} \mathrm{C}$ and weighed, tibia relative weight as a percentage of LBW was calculated, and then dry-ashed for 24 hour in a $600^{\circ} \mathrm{C}$ muffle furnace. Ash weight was expressed as a percentage of dried tibia weight. The economic efficiency was calculated as the price of LBW-total costs of raising a broiler chicks as relative to total raising costs which was estimated based upon local current prices at the experimental time. Statistical analysis of results was performed using the General Linear Models procedure of the SPSS software (SPSS, 2007), according to the follow general model:

$$
\mathrm{Y}_{\mathrm{ijk}}=\mu+\mathrm{M}_{\mathrm{i}}+\mathrm{T}_{\mathrm{j}}+\mathrm{MT}_{\mathrm{ij}}+\mathrm{e}_{\mathrm{ijk}}
$$

Where: $Y_{\mathrm{ijk}}$ : observed value, $\mu$ : overall mean, $\mathrm{M}_{\mathrm{i}}$ : level of ME effect (i: recommended (R), R-150 Kcal/Kg diet), $\mathrm{T}_{\mathrm{j}}$ : type of addition ( $\mathrm{j}$ : without, $\mathrm{Se}$, choline and mixture), $\mathrm{MT}_{\mathrm{ij}}$ : interaction effect of level of ME by type of addition, $\mathrm{e}_{\mathrm{ijk}}$ : random error.

Treatment means indicating significant differences $(\mathrm{P} \leq 0.01$ and $\mathrm{P} \leq 0.05)$ were tested using Duncan's multiple range test (Duncan, 1955).

\section{RESULTS AND DISCUSSION}

Performance: Effects of Se and/or choline as feed additives in broiler diets at low level of ME on LBW, LBWG and feed intake (FI) are shown in Table (2). The main effects of level of ME had insignificantly $(\mathrm{P}>0.05)$ affected LBW and LBWG at all periods studied except, LBW at 41 days and LBWG during the periods from 25 to 41 and 6 to 41 days, which was significantly ( $\mathrm{P} \leq 0.01$ ) affected (Table 2). It is clear that, chicks fed diet containing recommended level of ME (R)-150 Kcal/Kg diet had significantly higher values of LBW at 41 days and LBWG during the periods from 25 to 41 and 6 to 41 days (this may be due to the birds fed on low-ME diets consumed the same amount of energy due to increased FI), while, chicks fed diet containing R had significantly lower LBW and LBWG values during the same previous periods. Similar to the present findings Ragab (2013) found that chicks fed diet containing R-100 Kcal/Kg diet had higher LBW at 42 days and LBWG during the period from 5 to 42 days. While, no significant difference in final LBW (Giachetto et al., 2003 and Emam et al., 2014) and LBWG (Emam et al., 2014) was found by different energy levels in the birds diet over the range 2900 or $3200 \mathrm{Kcal} \mathrm{ME} / \mathrm{kg}$.

Type of addition had insignificant effect on LBW and LBWG at all periods studied, except, LBWG during the period from 6 to 12 days which was significantly $(\mathrm{P} \leq 0.01)$ affected (Table 2). As shown in Table 2, chicks fed $0.1 \mathrm{mg} \mathrm{Se} / \mathrm{Kg}$ diet as Sel-Plex had higher value of LBWG during the period from 6 to 12 days and those fed diet containing $0.1 \%$ choline had the lower value of LBWG during the same period, the differences between values of LBWG for chicks fed control diet and those fed diet containing $0.1 \%$ choline were not significant (Table 2).

Numerically, all type of addition increase $(\mathrm{P}>0.05) \mathrm{LBW}$ at 41 days and LBWG during the period from 6 to 41 days compared with those fed control diet. On the other hand, chicks fed $0.1 \%$ choline had higher values of LBW and LBWG during the period from 6 to 41 days, however, these did not reach a level of statistical significance (Table 2). Similar to the present results, Emam et al. (2014) reported that no significant difference in final LBW and LBWG was found by different levels of choline supplementation in 
Emam 
the triticale diets for broiler chicks (under summer conditions). While, Vogt (1994) found that choline supplementation improved growth. Likewise, some reports found no effect of different levels of Se or Se yeast on final LBW of the chickens (Habibian et al., 2013 and Shourrap at el., 2018), LBWG, FI and FC (Payne and Southern, 2005, Yoon et al., 2007 and Shourrap at el., 2018) and growth performance of broiler (Choct et al., 2004, Chen et al., 2013 and Boostani et al., 2015) However, Yang et al. (2012) show that Se yeast $(0.3 \mathrm{mg} / \mathrm{kg})$ could increase daily LBWG and FI by 8.92 and $3.99 \%$ and decrease FC by $4.84 \%$, respectively. Also, Balti et al. (2015) reported that average LBW at the end of the study, it was higher $(\mathrm{P} \leq 0.05)$ in the group with added $0.4 \mathrm{mg} / \mathrm{kg}$ Se as compared with no added Se and with the highest $\mathrm{Se}$ content in feed $(0.6 \mathrm{mg} / \mathrm{kg})$.

Interaction due to level of ME effect $\mathrm{X}$ type of addition (experimental treatments) had insignificantly $(\mathrm{P}>0.05)$ affected LBW and LBWG at all periods studied except, LBWG during the period from 6 to 12 days which was significantly $(\mathrm{P} \leq 0.01)$ affected (Table 2$)$. Chicks fed recommended level of ME with $0.1 \mathrm{mg}$ $\mathrm{Se} / \mathrm{Kg}$ diet as Sel-Plex had higher value of LBWG during the period from 6 to 12 days, however, those fed control diet had the lower value of LBWG during the same period (Table 2). Numerically, as shown in Table (2), all dietary treatments increase LBW at 41 days and LBWG during the period from 6 to 41 days compared with those fed control diet, however, these did not reach a level of statistical significance.

In this respect, El-sheikh and Ahmad (2006) demonstrated that supplementation of broilers diets with Sel-Plex significantly $(\mathrm{P} \leq 0.05)$ improved LBW at 6 weeks of age, $\mathrm{LBWG}$ and FC during the period from $0-6$ weeks compared to control group. The increasing of LBW with feeding Sel-Plex may be due to the findings of Arthur (1992) who reported that dietary Se improves the growth of broilers because Se plays an important part in regulatory metabolism, in that it plays an essential role in catalyzing the formation thyroid hormones and conversion of T4 to T3, which are important for normal growth and development (Jianhua et al., 2000).

Dietary level of ME effect was significant for FI at all periods studied (Table 2). It is clear that, chicks fed R-150 Kcal/Kg diet had significantly higher values of FI during all periods studied (this may be due to the bird's attempt at maintaining a normal energy intake), while, chicks fed control diet had significantly lower values of FI during the same periods.

Similar to the present findings, Ragab (2013) and Emam et al. (2014) found that FI was increased as well as FC was improved by low level of energy $(\mathrm{R}-100 \mathrm{Kcal} / \mathrm{Kg})$ in the broiler diet during the periods from 24 to 42 and 5 to 42 days as compared with chicks fed control diet. While, Giachetto et al. (2003) reported that birds fed with high dietary energy level (3200 Kcal ME/kg) had a lower FI and better FC. Dairo et al. (2010) found that, FI was lower at finisher phases for birds fed diets with low energy-high protein combination and low energy-low protein. In this respect, Dozier et al. (2006) reported that broilers consume diet to primarily meet energy requirements, while, other research by Mbajiorgu et al. (2011) failing to observe an effect of dietary energy on FI.

Type of addition had significant $(\mathrm{P} \leq 0.01)$ effect on FI at all periods studied, except, during the period from 13 to 24 days which was insignificantly affected (Table 2). As shown in Table (2), the highest significant value of FI during the finisher and over all experimental period achieved by addition of $0.1 \mathrm{mg}$ $\mathrm{Se} / \mathrm{kg}$ diet. Chicks fed diet containing $0.1 \%$ choline had the lower value of FI during the period from 25 to 41 days, while, chicks fed control diet had the lower value of FI during the periods from 6 to 12 and 6 to 41 days (the differences between values of FI for chicks fed control diet and those fed diet containing $0.1 \%$ choline were not significant during the periods from 25 to 41 and 6 to 41 days), (Table 2).

In this respect, Emam et al. (2014) found that $0.1 \%$ choline supplementation (under summer conditions) decrease FI and improve FC during the period from 5 to 42 days of age as compared with those fed choline un-supplement diet.

Interaction due to level of ME effect $\mathrm{X}$ type of addition had significantly affected FI during all periods studied (Table 2). Chicks fed diet containing R-150 Kcal/Kg diet with $0.05 \mathrm{mg} \mathrm{Se} / \mathrm{Kg}$ diet and $0.05 \%$ choline had higher values of FI during the periods from 6 to 12, 13 to 24 and 6 to 41 days, however, those fed control diet had the lower values of FI during the periods from 6 to 12, 25 to 41 and 6 to 41 days (Table 2). In this regard, Emam et al. (2014) indicated that chicks fed control diets with choline supplement had significantly lower value of FI during the period from 5 to 42 days.

Data presented in Table (3) indicate the main effect of level of ME was significant $(\mathrm{P} \leq 0.05$ and $\mathrm{P} \leq 0.01)$ for FC and CPC during the periods from 6 to 12 and 25 to 41 days and CCR during the periods from 25 to 41 and 6 to 41 days. Chicks fed diet containing recommended level of ME had the best FC and CPC values 
Emam 
during the period from 6 to 12 days. Chicks fed R-150 Kcal/Kg had the best FC, CPC and CCR during the period from 25 to 41 days, and those fed R-150 Kcal/Kg had the best CCR during the period from 6 to 41 days (Improvement in FC, CPC and CCR of broiler appears to be due to the increase in LBW and LBWG). In this respect, Kamran et al. (2008) reported that LBWG, FCR were adversely affected and FI increased linearly $(\mathrm{P} \leq 0.05)$, while, $\mathrm{PER}$ and EER were decreased $(\mathrm{P} \leq 0.05)$, during finisher and overall experimental periods as a result of lowering the dietary $\mathrm{CP}$ and $\mathrm{ME}$ content, however, EER was decreased with low-ME diets (Kamran et al., 2008). Also, increasing dietary energy level could improve FC rate of broilers by reducing FI (Dozier et al., 2006 and Ghaffari et al., 2007). The results cleared that type of addition and interaction due to level of ME effect X type of addition had insignificant effect on FC, CPC and CCR during all periods studied, except, during the period from 6 to 12 days which was significantly $(\mathrm{P} \leq 0.01)$ affected (Table 3).

As shown in Table (3), chicks fed diet containing $0.05 \mathrm{mg} \mathrm{Se} / \mathrm{Kg}$ diet and $0.05 \%$ choline had worst values of FC, CPC and CCR during the period from 6 to 12 days of age, while, those fed $0.1 \mathrm{mg} \mathrm{Se} / \mathrm{Kg}$ diet as Sel-Plex had best values of FC, CPC and CCR during the same period. As shown in Tables (2 and 3), numerical improvements in LBW, LBWG and improved FC and CCR were frequently observed when addition of $0.1 \%$ choline during the period from 6 to 41 days of age.

Similarly, Emam et al. (2014) indicated that $0.1 \%$ choline supplementation (under summer conditions) improve $(\mathrm{P}>0.05) \mathrm{CPC}, \mathrm{CCR}$ and increase $(\mathrm{P}>0.05)$ GR, PI during the period from 5 to 42 days as compared with those fed cho. un-supplement diet $(0.0 \%)$, however, these did not reach a level of statistical significance. Waldroup et al. (2006) reported that, numerical improvements in LBW and significantly improved FC were frequently observed when addition of $1000 \mathrm{mg}$ of choline $/ \mathrm{kg}$ over the birds fed the unsupplemented diets at 35, 42, 49, and $56 \mathrm{~d}$ of age. Dilger et al. (2007) reported that supplementation of the cho. free basal diet with graded levels of choline resulted in linear increases in LBWG, FI and improved FC. Also, Jadhav et al. (2008) found that a significant increase in LBW and significant improvement in FC was observed in choline supplemented broilers when compared with control birds. These results disagree with those of Waldroup and Fritts (2005) who reported that choline supplementation had no significant effect on FC. Moreover, Rafeeq et al. (2011) found that the supplementation choline as choline chloride might have disturbed the ion balance and resulted in lower FI and LBWG.

As shown in Table (3), chicks fed diet containing recommended level of ME with $0.1 \mathrm{mg} \mathrm{Se} / \mathrm{Kg}$ diet as Sel-Plex had the best values of FC and CPC during the period from 6 to 12 days of age. While, chicks fed diet containing R-150 Kcal $/ \mathrm{Kg}$ with $0.05 \mathrm{mg} \mathrm{Se} / \mathrm{Kg}$ diet and $0.05 \%$ choline had worst values of FC, CPC and CCR during the during the same period.

Data presented in Table (4) indicate the main effect of level of ME was insignificant for GR and PI at all periods studied, except, GR during the period from 6 to 41 days and PI during the period from 25 to 41 days, which was significantly ( $\mathrm{P} \leq 0.05$ and $\mathrm{P} \leq 0.01)$ affected (Table 4). Chicks fed diet containing recommended level of ME had lower values of GR and PI during the same previous periods, and those fed R-150 Kcal/ $\mathrm{Kg}$ had higher values of GR and PI during the same period.

Type of addition had insignificant effect on GR and PI at all periods studied, except, the period from 6 to 12 days, which was significantly ( $\mathrm{P} \leq 0.05$ and $\mathrm{P} \leq 0.01)$ affected (Table 4). Chicks fed $0.1 \mathrm{mg} \mathrm{Se} / \mathrm{Kg}$ diet had higher values of GR and PI during the period from 6 to 12 days (Table 4).

Numerically, as shown in Table (4), all type of addition insignificant increase (P>0.05) GR and PI during the period from 6 to 41 days especially when addition of $0.1 \%$ choline as compared with those fed control diet. In this respect, Dilger et al. (2007) determined that the minimal concentration of dietary choline for chicks to achieve maximal growth rate was $722 \mathrm{mg} / \mathrm{kg}$ diet is optimal for normal growth.

The results cleared that interaction due to level of ME effect $\mathrm{X}$ type of addition had insignificant effect on GR and PI at all periods studied, except, GR during the periods from 6 to 12 and 13 to 24 days and PI during the period from 6 to 12 days which was significantly $(\mathrm{P} \leq 0.01)$ affected (Table 4$)$. Chicks fed diet containing recommended level of ME with $0.1 \mathrm{mg} \mathrm{Se} / \mathrm{Kg}$ diet as Sel-Plex had higher values of GR and PI during the period from 6 to 12 days of age. It can be concluded that ME can be reduced from the recommended level by $150 \mathrm{Kcal} / \mathrm{Kg}$ without affecting LBW, LBWG, FI, FC, CPC, CCR, GR and PI (Tables 2, 3 and 4). Numerically, as shown in Tables (2, 3 and 4), all dietary treatments increase LBW, LBWG, GR and PI during the period from 6 to 41 days compared with those fed control diet, however, these did not reach a level of statistical significance. It can be concluded that, dietary ME can be reduced from the 
Egyptian J. Nutrition and Feeds (2018) 
ratio. However, Dozier and Moran (2002) reported that feeding broiler diets formulated to contain suboptimum levels of CP and ME impaired the quantity and yield of carcass parts.

Emam et al. (2014) indicated that under summer conditions neither choline nor interaction between choline $\mathrm{x}$ level of ME Kcal/Kg diet had any significant effect on carcass characteristics. Waldroup and Fritts (2005) demonstrated that addition of $1000 \mathrm{mg} / \mathrm{kg}$ of choline significantly improved breast meat yield at $42 \mathrm{~d}$ but not at 49 days. While, Waldroup et al. (2006) reported that, no significant effects on dressing\% and significant improvements in breast meat yield were frequently observed when addition of $1000 \mathrm{mg}$ of choline/kg over the birds fed the unsupplemented diets at 42,49 , or 56 days of age.

Blood constituents: As shown in Table (6), no significant $(\mathrm{P}>0.05)$ differences were detected in blood constituents due dietary ME Kcal/Kg diet, type of addition and interaction due to level of ME effect X type of addition, except, interaction due to level of ME effect $\mathrm{X}$ type of addition, which was significantly $(\mathrm{P} \leq 0.05)$ affected of total leucocytes. Chicks fed diet containing $\mathrm{R}$ with $0.1 \%$ choline had lower value of total leucocytes, while, those fed diet containing R-150 Kcal/Kg diet with $0.1 \%$ choline had higher value of total leucocytes at the end of the experiment. No significant differences were observed in blood constituents as a result of choline\%, dietary level of $\mathrm{ME} \mathrm{Kcal} / \mathrm{Kg}$ diet and interaction between choline\% x dietary ME (Emam et al., 2014).

In addition, Romaniiuk et al. (1995) showed that there was no significant effect of Sel-Plex on hemoglobin (HB). Se deficiency does not necessarily affect neutrophil numbers but rather different aspects of neutrophil function. Se deficit damages both cellular and humoral immunity (Arthur et al., 2003).

Se stimulates the immune system, strengthening proliferation of activated $\mathrm{T}$ lymphocytes (Rayman, 2000). Daily intake of $200 \mu \mathrm{g}$ of Se causes increased reaction of lymphocytes to antigenic stimulation and increase of their ability to mature to cytotoxic lymphocytes destroying tumour cells. The activity of natural killers increases, too. This mechanism is closely connected with increased numbers of receptors for interleukin-2 on the surface of the activated lymphocytes and natural killers. These interactions are critical for clonal expansion and differentiation to cytotoxic T cells (Rayman, 2000 and Arthur et al., 2003).

The cell-mediated immunity in broiler chickens (lymphocyte proliferation ratio) increased linearly with dietary organic Se concentration (Rama Rao et al., 2013).

The effects of level of ME, type of addition and treatments on blood plasma GSH-PX activity from Cobb strain are presented in Table (6). GSH-PX activity were significantly $(\mathrm{P} \leq 0.01)$ affected by level of ME and type of addition. Chicks fed diet containing recommended level of ME had higher value of GSH-PX at 41 days, and those fed R-150 Kcal/Kg had lower value of GSH-PX. As shown in Table (6), chicks fed $0.1 \mathrm{mg}$ $\mathrm{Se} / \mathrm{Kg}$ diet as Sel-Plex had higher value of GSH-PX at 41 days and those fed control diet had the lower value of GSH-PX. Interaction due to level of ME effect X type of addition had insignificant effect on GSH-PX. Similar to the present results, Shourrap at el. (2018) demonstrated that at five weeks of age, supplementation of broiler diet with organic Se $(0.4,0.5$ and $0.6 \mathrm{ppm} / \mathrm{kg})$ increased activities of GSH-PX compared to control group $(0.2 \mathrm{ppm} / \mathrm{kg}$ Se enriched yeast). Boostani et al. (2015) reported that dietary Se supplementation raised activity of GSH-PX in serum and tissues. Further more, Chen et al. (2013) reported that oxidation resistance of broiler was significantly improved with higher level of dietary Se. Hu et al. (2012) observed that the maximum response of serum GSH-Px activity to dietary Se occurred by the $0.15 \mathrm{mg} \mathrm{Se} / \mathrm{kg}$ in broiler diet. Balti et al. (2015) stated that at the end of the study, significantly higher $(\mathrm{P} \leq 0.01)$ enzymatic activity was determined in groups with $0.4 \mathrm{mg} / \mathrm{kg}$ and $0.6 \mathrm{mg} / \mathrm{kg}$ added Se compared to groups with lower levels of Se in their diets $(0 \mathrm{mg} / \mathrm{kg}$ and $0.2 \mathrm{mg} / \mathrm{kg})$. Lipid peroxidation in plasma decreased, while activities of GPx and glutathione reductase in plasma increased linearly with Se. GSH-PX activity was not correlated with dietary Se concentrations (Zoidis et al., 2014).

Chemical composition of broiler meat: Level of ME had insignificantly affected chemical composition of broiler meat (Table 7). Type of addition and interaction due to level of ME effect X type of addition had insignificant effect on chemical composition of broiler meat, except, moisture\%, which was significantly $(\mathrm{P} \leq 0.01)$ affected (Table 7). Carcass part insignificantly influenced chemical composition of broiler meat except, protein and fat\% which was significantly affected. Rear part had higher fat\% than the breast part (5.28 vs. $1.00 \%$ ), however, breast part had higher protein\% (consequently lower fat\%) than rear part (Table $7)$.

Similarly, Ragab and Osman (2008), revealed no significant difference among dietary treatments as increasing energy level in chemical composition of broiler meat\%. Also, Sevcikova et al. (2006) did not 
Egyptian J. Nutrition and Feeds (2018) 
find any differences between control (no added Se) and Se-yeast group in dry matter, protein and intramuscular fat of breast and thigh muscles of broilers. However, Pappas et al. (2012) found that the intramuscular fat content of breast muscle tissue increased as the supplemented level of Se increased.

Generally, the discrepancies in responses often observed in the researches or studies in chicks fed energy, Se and/or choline supplemented diets can be partly due to other factors. Such as, the degree of energy restriction, diets composition, the strain and age of the chickens used and rearing environment conditions, whether or $\mathrm{C} / \mathrm{P}$ ratio imbalances. Also, may be differences in experimental designs and conditions between these previous studies and our study could be responsible for the variations observed. In this respect, Havenstein et al. (2003) demonstrated that bird sex, age and strain influenced the response of growing chicken to level of dietary energy, also highlighted other factors that may effect the comparison of energy level such as nutrient density and the nature of diet ingredients.

Table (7): Effect of dietary energy levels with or without selenium and choline supplementation on chemical composition of broiler meat $\%$.

\begin{tabular}{|c|c|c|c|c|c|c|}
\hline Item & & Moisture & Protein & Fat & Ash & NFE \\
\hline \multicolumn{7}{|c|}{ Level of metabolizable energy (ME) Kcal/Kg (L) } \\
\hline Recommended (R) & & 74.34 & 19.14 & 3.20 & 2.10 & 1.23 \\
\hline $\mathrm{R}-150$ & & 73.94 & 19.42 & 3.08 & 2.34 & 1.22 \\
\hline SEM $^{1}$ & & 0.18 & 0.61 & 0.64 & 0.17 & 0.01 \\
\hline P-value & & 0.116 & 0.745 & 0.898 & 0.326 & 0.678 \\
\hline \multicolumn{7}{|l|}{ Type of addition(T) } \\
\hline Without $^{2}$ & & $74.21^{\mathrm{b}}$ & 19.92 & 2.73 & 1.90 & 1.23 \\
\hline Selenium $(\mathrm{Se})^{3}$ & & $74.01^{\mathrm{bc}}$ & 18.73 & 3.41 & 2.62 & 1.22 \\
\hline Choline $^{4}$ & & $73.30^{c}$ & 19.84 & 3.44 & 2.19 & 1.22 \\
\hline Mixture $^{5}$ & & $75.03^{\mathrm{a}}$ & 18.62 & 2.96 & 2.16 & 1.23 \\
\hline SEM & & 0.25 & 0.86 & 0.90 & 0.24 & 0.01 \\
\hline P-value & & 0.001 & 0.580 & 0.930 & 0.231 & 0.964 \\
\hline \multicolumn{7}{|l|}{ Carcasse part } \\
\hline Front & & 74.42 & $21.26^{\mathrm{a}}$ & $1.00^{\mathrm{b}}$ & 2.10 & 1.23 \\
\hline Rear & & 73.86 & $17.30^{\mathrm{b}}$ & $5.28^{\mathrm{a}}$ & 2.34 & 1.23 \\
\hline SEM & & 0.26 & 0.24 & 0.19 & 0.17 & 0.01 \\
\hline P-value & & 0.136 & $<0.001$ & $<0.001$ & 0.330 & 0.761 \\
\hline \multicolumn{7}{|l|}{$\mathrm{L} \times \mathrm{T}$ (treatments) } \\
\hline \multirow[t]{5}{*}{ 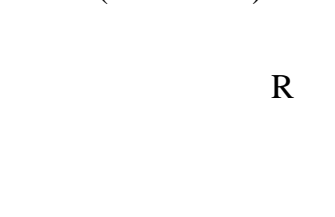 } & Without & $73.59^{\mathrm{cd}}$ & 19.94 & 3.44 & 1.80 & 1.23 \\
\hline & Selenium & $74.63^{b c}$ & 18.23 & 3.49 & 2.43 & 1.23 \\
\hline & Choline & $73.39^{\mathrm{d}}$ & 19.78 & 3.26 & 2.35 & 1.22 \\
\hline & Mixture & $75.75^{\mathrm{a}}$ & 18.61 & 2.59 & 1.81 & 1.23 \\
\hline & Without & $74.84^{\mathrm{ab}}$ & 19.91 & 2.03 & 2.01 & 1.22 \\
\hline \multirow{3}{*}{$\mathrm{R}-150$} & Selenium & $73.39^{\mathrm{d}}$ & 19.24 & 3.33 & 2.82 & 1.22 \\
\hline & Choline & $73.22^{\mathrm{d}}$ & 19.91 & 3.63 & 2.02 & 1.23 \\
\hline & Mixture & $74.30^{\mathrm{bcd}}$ & 18.63 & 3.33 & 2.51 & 1.23 \\
\hline SEM & & 0.35 & 1.21 & 1.28 & 0.34 & 0.01 \\
\hline P-value & & 0.003 & 0.969 & 0.846 & 0.506 & 0.902 \\
\hline
\end{tabular}

Economic efficiency (EEf): Results in Table (8) showed that, EEf values during the period from 6 to 41 days of age improved in chicks fed all experimental diets, except, chicks fed diet containing recommended level of ME with $0.05 \mathrm{mg} \mathrm{Se} / \mathrm{Kg}$ diet as Sel-Plex plus $0.05 \%$ choline (the lowest corresponding values, being 0.126 and $95.74 \%$, respectively), as compared with those fed the control diet. Chicks fed diet 7 (R-150 $\mathrm{Kcal} / \mathrm{Kg}$ diet plus $0.1 \%$ choline) had the best Economic and relative efficiency values being 0.251 and $191.34 \%$, respectively, followed by chicks fed diet $8(\mathrm{R}-150 \mathrm{Kcal} / \mathrm{Kg} \operatorname{diet}+0.05 \mathrm{mg} \mathrm{Se} / \mathrm{Kg} \operatorname{diet}+0.05 \%$ choline), being, (0.248 and $188.43 \%$, respectively), then chicks fed diet 5 (R-150 Kcal/Kg diet), being $(0.221$ and $168.21 \%$, respectively) as compared with those fed the control diet. The relative efficiency varied between $100.0 \%$ to $191.34 \%$, which is of minor importance relative to other factors of production. So, 


\section{Emam}

\section{REFERENCES}

A.O.A.C. (1990). Association of Official Analytical Chemists, Official Methods of Analysis. 15th Edition, Washington, D.C, USA.

Abdel-Samai, S., A. G. Abdallah, M. Ahmed, S. Abou-El-Wafa, and M. Shaaban (2007). Optimal carbohydrates to fat ratio in broiler diets containing the same energy level. 4th World Poultry Conference 27- 30 March, Sharm El- Sheikh, Egypt (255-267).

Arthur, J.R. (1992). Selenium metabolism and function. Proceedings of the Nutrition Society of Australia. 17: 91-97.

Arthur, J. R., R.C. McKenzie, and G.J. Beckett (2003). Selenium in the immune system. Journal of Nutrition, 133, 1457-1459.

Balti, M.Z., M. D. Starcevi, M. Basi, A. Zenunovi, J. Ivanovi, R. Markovi, J. Janji, and H. Mahmutovi (2015). Effects of selenium yeast level in diet on carcass and meat quality, tissue selenium distribution and glutathione peroxidase activity in ducks. Anim. Feed Sci. Technol., 210: 225-233.

Boostani, A., A.A. Sadeghi, S.N. Mousavi, M. Chamani, and N. Kashan (2015). Effects of organic, inorganic, and nano-Se on growth performance, antioxidant capacity, cellular and humoral immune responses in broiler chickens exposed to oxidative stress. Livestock Science. 178: 330-336

Briens, M., Y. Mercier, F. Rouffineau, V. Vacchina, and P.A. Geraert (2013). Comparative study of a new organic selenium source v. seleno-yeast and mineral selenium sources on muscle selenium enrichment and selenium digestibility in broiler chickens. Br. J. Nutr. 110:617-624.

Burk, R.F., and K.E. Hill (2015). Regulation of selenium metabolism and transport. In: In: Bowman, B.A., Stover, P.J. (Eds.), Annual Review of Nutrition, 35. pp. 109-134.

Cerrate, S., Z. Wang, C. Coto, F. Yan, and P.W. Waldroup (2007). Choice feeding as a means of identifying differences in nutritional needs of broiler strains differing in performance characteristics. Inter. J. of Poult. Sci., 6: 713-724.

Chen, G., J. Wu, and C. Li (2013). The effect of different selenium levels on production performance and biochemical parameters of broilers. Italian Journal of Animal Science, 12, 486-491.

Choct, M., A.J. Naylor, and N. Reinke (2004). Se supplementation affects broiler growth performance, meat yield and feather coverage. Br. Poult. Sci., 45(5),677-683.

Dairo, F. A. S., A. O. K. Adesehinwa, T. A. Oluwasola1, and J. A. Oluyemi (2010). High and low dietary energy and protein levels for broiler chickens. Afr. J. Agric. Res. Vol. 5: 2030-2038,

Dalgaarda, T. S., M. Briensb, R. M. Engberga, and C. Lauridsena (2018). The influence of selenium and selenoproteins on immune responses of poultry and pigs. Anim. Feed Sci. Technol., 238: 73-83.

Dilger, R.N., T. A. Garrow, and D. H. Baker (2007). Betaine can partially spare choline in chicks but only when added to diets containing a minimal level of choline. J.Nutr., 137:2224-2228.

Dozier III, W.A., and Jr, E.T. Moran (2002). Dimension and light reflectance of broiler breast fillets: influence of strain, sex, and feeding regimen. J. Appl. Poult. Res., 11: 202-208.

Dozier III, W. A., C. J. Price, M. T. Kidd, A. Corzo, J. Anderson, and S. L. Branton (2006). Growth performance, meat yield, and economic responses of broilers fed diets varying in metabolizable energy from thirty to fifty-nine days of age. J. Appl. Poult. Res., 15: 367-382.

Duncan, D. B. (1955). Multiple range and multiple F tests. Biometrics, 11: 1-42.

Dunlevy, L. P. E., L. S. Chitty, K. A. Burren, K. Doudney, T. S. Mikic, P. Stanier, R. Scott, A. J. Copp, and N. D. E. Greene (2006). Excess methionine suppresses the methylation cycle and inhibits neural tube closure in mouse embryos. FEBS Letters, 11: 2803-2807.

Dunshea, F.R., D.J. Cadogan, and G.G. Partridge (2009). Dietary betaine and ractopamine combine to increase lean tissue deposition in finisher pigs, particularly gilts. Anim. Prod. Sci., 49: 65-70. 
El-sheikh, T. M., and N. S. Ahmad (2006). An attempt to alleviate heat stress of broiler chicks (during summer season) through stocking density, dietary organic selenium (sel-plex) and vitamin E-selemium. Egypt. Poult. Sci., 26: 1587-1611.

Emam, R.M.S., M.M.M. Namra, and H.M. Abdel Wahed (2014). Effect of dietary energy level on the broiler response to choline supplements during summer season. Egyptian J. Nutrition and Feeds, 17: 483-494.

European Commission (2014). European Union Register of Feed Additives Pursuant to Regulation (EC) No $1831 / 2003,182$ th ed.

Finkelstein, J.D. (2000). Homocysteine: a history in progress. Nutr. Rev., 58: 193-204.

Garlich, J. D. (1979). Regulation of lipid metabolism in avian species. Federation Proceedings, 38: 26162623.

Garrow, T.A. (2007). Choline. In: Handbook of vitamins. Zempleni J, Rucker RB, McCormick DB, Suttie JW, editors. 4th ed. Boca Raton (FL): CRC Press. P. 459-487.

Ghaffari, M., M. Shivazad, M. Zaghari, and R. Taherkhani (2007). Effects of different levels of metabolizable energy and formulation of diet based on digestible and total amino acid requirements on performance of male broiler. Int. J. Poult. Sci., 6:276-279.

Giachetto, P. F., E. N. Guerreiro, J. A. Ferro, M. I. T. Ferro, R. L. Furlan, and M. Macari (2003). Performance and hormonal profile in broiler chickens fed with different energy levels during post restriction period. Pesq. agropec. bras., Brasília, v. 38, n. 6, p. 697-702, jun.

Habibian, M., S. Ghazi, M.M. Moeini, and A. Abdolmohammadi (2013). Effects of dietary selenium and vitamin $\mathrm{E}$ on immune response and biological blood parameters of broilers reared under thermoneutral or heat stress conditions. International Journal of Biometeorology, 58, 741-752.

Harms, H.R., N. Ruiz, and R.D. Miles (1990). Research note: conditions necessary for a response by the commercial laying hen to supplemental choline and sulfate. Poult. Sci., 69: 1226-1229.

Havenstein, G.B., P.R. Ferket, and M.A. Qureshi (2003). Growth livability, and feed conversion of 1957 versus 2001 broilers when fed representative 1957 and2001 broiler diets. Poult. Sci., 82: 1500-1508.

Hu, C.H., Y.L. Li, L. Xiong, H.M. Zhang J. Song, and M.S. Xia (2012). Comparative effects of nano elemental selenium and sodium selenite on selenium retention in broiler chickens. Anim. Feed Sci. Technol., 177: 204-210.

Jadhav, N. V., V. Nagbhushana, S. Maini, and S. M. Kartikesh (2008). An Evaluation of comparative effects of feeding synthetic and herbal choline on broiler performance, nutrient balance and serum activities. Veterinary World, 1(10): 306-309.

Jianhua, H., A. Ohtsuka, and K. Hayashi (2000). Selenium influences growth via thyroid hormone status in broiler chickens. Br. J. Nutr., 84(5): 727-32.

Kamran, Z., M. Sarwar, M. Nisa, M. A. Nadeem, S. Mahmood, M. E. Babar, and S. Ahmed (2008). Effect of Low-Protein Diets Having Constant Energy-to-Protein Ratio on Performance and Carcass Characteristics of Broiler Chickens from One to Thirty-Five Days of Age. Poult. Sci., 87:468-474

Klasing, K.C. (1998). Nutritional modulation of resistance to infectious diseases. Poult. Sci., 77: 1119-1125.

Li, J. L., and R. A. Sunde (2016). Selenoprotein transcript level and enzyme activity as biomarkers for selenium status and selenium requirements of chickens (Gallus gallus). PLoS One 11.

Mahmoud, K. Z., and F. W. Edens (2003). Influence of selenium sources on age-related and mild heat stressrelated changes of blood and liver glutathione redox cycle in broiler chickens (Gallus domesticus). Comp. Biochem. Physiol. 136B, 921-934.

Martinez, A. C., C. M. Parsons, and D. H. Baker (2006). Effect of microbial phytase and citric acid on phosphorus bioavailability, apparent metabolizable energy, and amino acid digestibility in distillers dried grains with solubles in chicks. Poult. Sci., 85:470-475

Mbajiorgu, C.A., J.W. Ngambi, and D.D. Norris (2011). Voluntary feed intake and nutrient composition in chickens. Asian J. Anim. Vet. Adv. 6, 20-28. 


\section{Emam}

McDevitt, R.M., S. Mack, and I.R. Wallis (2000). Can betaine partially replace or enhance the effect of methionine by improving broiler growth and carcase characteristics. Br. Poult. Sci., 41 (4): 473-480.

McDowell, L.R. (2000). Vitamins in animal and human nutrition, Second Edition, Iowa State University Press. ISBN 0-8138-2630-6, p. 577.

National Research Council, NRC (1994). Nutrient Requirements of Poultry. 9th revised edition. National Academy Press. Washington, D.C., USA.

Niculescu, M. D., C. N. Craciunescu, and S. H. Zeisel (2006). Dietary choline deficiency alters global and gene-specific DNA methylation in the developing hippocampus of mouse fetal brains." FASEB Journal: Official Publication of the Federation of American Societies for Experimental Biology 20, 1: 43-49.

North, M. O. (1981). Commercial Chicken Production Manual, 2nd Edition. AVI Publishing Company Inc, USA.

Papazyan, T.T., S.A. Denev, and P.F. Surai (2006). Selenium in poultry nutrition: lessons from research and wild nature. Krmiva Zagreb. 5:275-283.

Pappas, A.C., E. Zoidis, G. Papadomichelakis, and K. Fegeros (2012). Supranutritional selenium level affects fatty acid composition and oxidative stability ofchicken breast muscle tissue. J. Anim. Physiol. Anim. Nutr., 96: 385-394.

Payne, R. L., and L. L. Southern (2005). Comparison of inorganic and organic selenium sources for broilers. J. Poult. Sci., 84:898-902.

Payne, R.L., T.K. Lavergne, and L.L. Southern (2005). Effect of inorganic versus organic selenium on hen production and egg selenium concentration. Poult. Sci., 84:232-237.

Pillai, P. B., A. C. Fanatico, K.W. Beers, M.E. Blair, and J.L. Emmert (2006). Homocysteine remethylation in young broilers fed varying levels of methionine, choline, and betaine. Poult. Sci., 85: 90-95.

Rafeeq, M., T. N. Pasha, M. M. Tariq, and M. A. Bajwa (2011). Performance of broiler chicken in early life on methionine deficient feed with added choline and betaine. Int. J. Livest. Prod. 2: 142-144.

Ragab, M. S. (2013). Impact of betaine supplementation to triticale diets varying in their metabolizable energy content on broiler performance during summer season. Egyptian J. Nutrition and Feeds, 16: 113129.

Ragab, M. S., and A. M. R. Osman (2008). Effect of feeding high dietary energy levels on productive performance of broiler chicks during the finisher period. Egypt. Poult. Sci., 28: 799-814.

Rama Rao, S.V., B. Prakash, M.V.L.N. Raju, A.K. Panda, S. Poonam, and O.K. Murthy (2013). Effect of supplementing organic selenium on performance, carcass traits, oxidative parameters and immune responses in commercial broiler chickens. Asian Australasian Journal of Animal Sciences, 26, 247-252.

Rayman, M.P. (2000). The importance of selenium to human health. Lancet, 356, 233-241.

Romaniiuk, K., M. Michalski, R. Scol, and M.G. Szelagtwiescz (1995). Influence of selenium and systamex (Oxfendazole) on gastrointestinal parasites in sheep during growth and pregnancy. Medycyna Weterynaryjna, 51:462-464.

Rotruck, J.T., A.L. Pope, H.E. Ganther, A.B. Swanson, D.G. Hafeman, and W.G. Hoekstra (1973). Selenium: biochemical role as a component of glutathione peroxidase. Science 179: 585-590.

Sevcikova, S., M. Skrivan, G. Dlouha, and M. Koucky (2006). The effect of selenium source on the performance and meat quality of broiler chickens. Czech. J. Anim. Sci., 51:449-457.

Shourrap, M.I., M. Sh. Abdo, H.A. Thabet, and M.A.M. Abdelaziz (2018). Antioxidant activity, se deposition and growth performance of broilers as affected by selenium-enriched yeast. Egypt. Poult. Sci., 38: $35-50$.

Singh, H., S. Sodhi, and R. Kaur (2006). Effects of dietary supplements of selenium, vitamin E or combinations of the two on antibody responses of broilers. Br. Poult. Sci., 47: 714-719.

SPSS (2007). User's Guide: Statistics. Version 16. SPSS Inc. Chicago, IL, USA. 
Upton, J.R., F.W. Edens, and P.R. Ferket (2008). Selenium yeast effect on broiler performance. Int. J. Poult. Sci., 7:798-805.

Utterback, P.L., C.M. Parsons, I. Yoon, and J. Butler (2005). Effect of supplementing selenium yeast in diets of laying hens on egg selenium content. J. Poult. Sci., 84:1900-1901.

Vogt, H. (1994). Can methionine be partially replaced with choline in broiler diet? Poult. Abst., 20: 3385.

Waldroup, P.W., and C.A. Fritts (2005) Evaluation of separate and combined effects of choline and betaine in diets for male broilers. Int. J. Poult. Sci., 4: 442-448.

Waldroup, P.W., M.A. Motl, F. Yan, and C.A. Fritts (2006). Effects of Betaine and choline on response to methionin supplementation to Broiler diets formulated to industry standards. J. Appl. Poult. Res., 15: 5871.

Wang, Y.Z., Z.R. Xu, and G. Feng (2004). The effect of betaine and DL- methionine on growth performance and carcass characteristics in meat ducks. Anim. Feed Sci. Technol.,116: 151-159.

Workel, H.A., Tb. Keller, A. Reeve, and A. Lauwaerts (1999). Choline-The rediscovered vitamin. Poult. Int., April: 44-47.

Wu, G., and A. Davis (2005). Interrelationship among methionine, choline, and betaine in channel catfish, Ictalurus punctatus. J. World Aquac. Soc. 36, 337-345.

Yang, Y.R., F.C. Meng, P. Wang, Y.B. Jiang, Q.Q. Yin, J. Chang, R.Y. Zuo, Q.H. Zheng, and J.X. Liu (2012): Effect of organic and inorganic selenium supplementation on growth performance, meat quality and antioxidant property of broilers. African Journal of Biotechnology, 11, 3031-3036.

Yoon, I., T.M. Werner, and J.M. Butler (2007). Effect of source and concentration of selenium on growth performance and selenium retention in broiler chickens. J. Poult. Sci., 86:727-730.

Zeisel, S.H., K.A. daCosta, P.D. Franklin, E.A. Alexander, J.T. Lamont, N.F. Sheard, and A. Beiser (1991) Choline, an essential nutrient for humans. FASEB J., 5: 2093-2098.

Zhang, Y. Q., C. O. Benedict, and T. F. William (2008). Bacterial reduction of selenite to elemental selenium utilizing molasses as a carbon source. Bioresource Technology, 5, 1267-1273.

Zoidis, E., N. Demiris, A. Kominakis, and A.C. Pappas (2014). Meta-analysis of selenium accumulation and expression of antioxidant enzymes in chicken tissues. Animal 8, 542-554. 


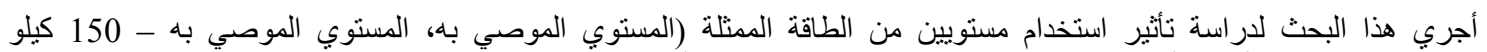

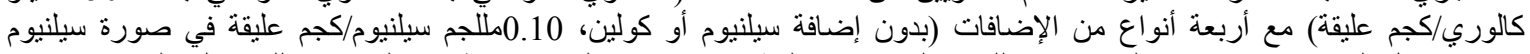

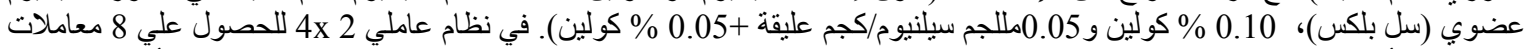

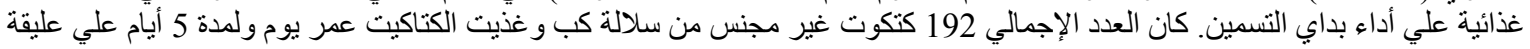
المقارنة.

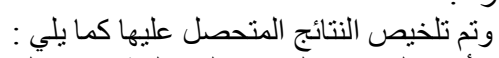

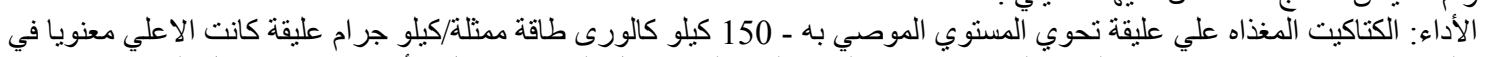

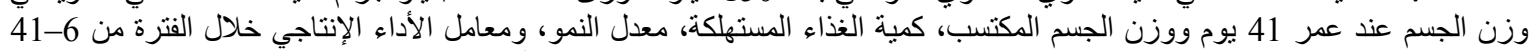

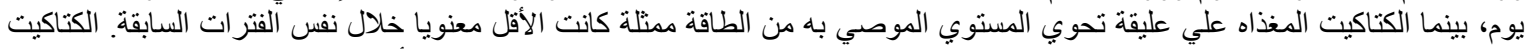

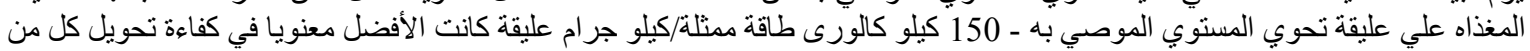

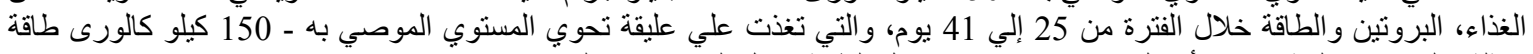

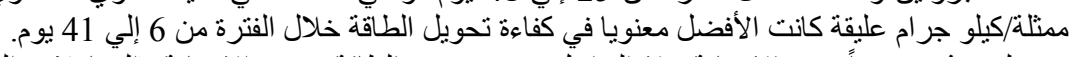

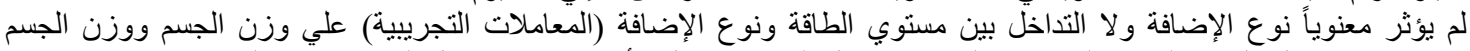

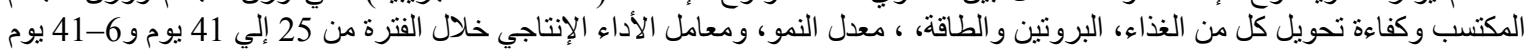

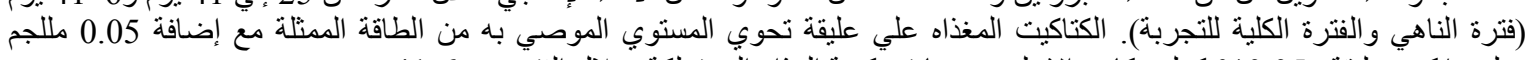

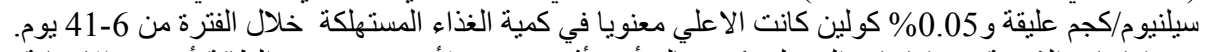

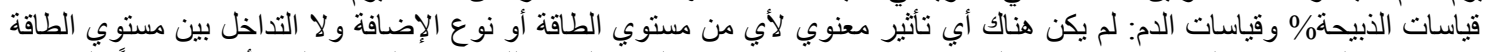

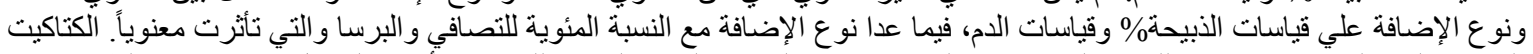

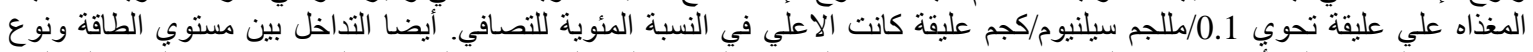

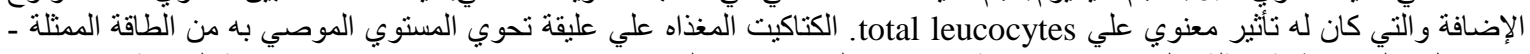

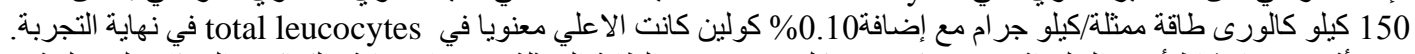

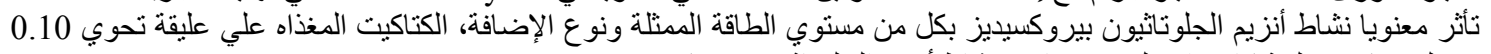

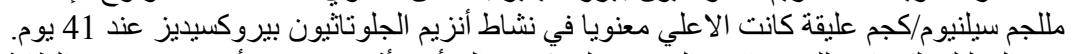

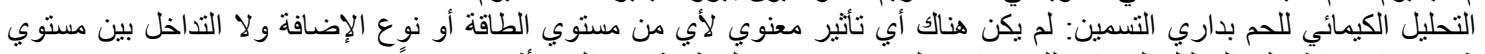

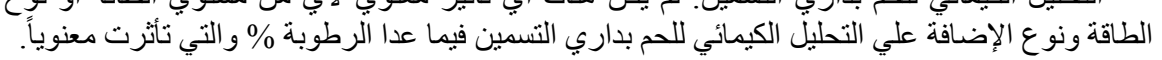

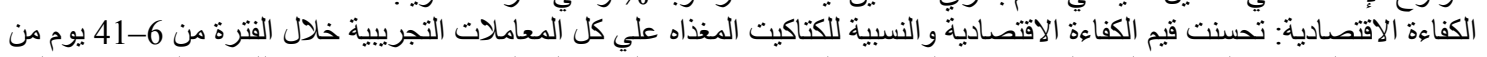

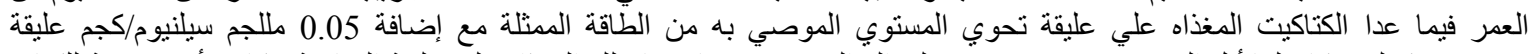

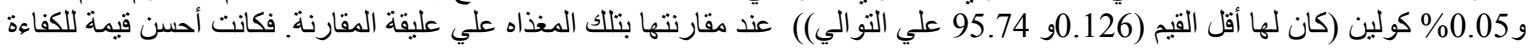

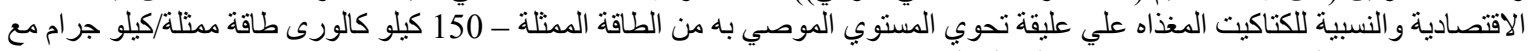

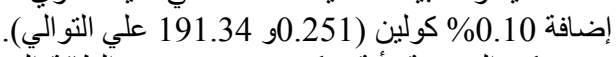

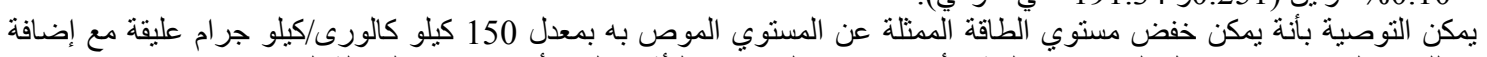

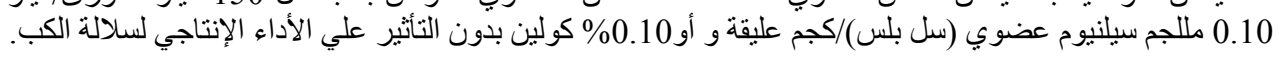

